\title{
SOCIAL NETWORKING WEBSITES IN INDIA AND THE UNITED STATES: A CROSS-NATIONAL COMPARISON OF ONLINE PRIVACY AND COMMUNICATION
}

\author{
Bryan A. Marshall, Georgia College \& State University, bryan.marshall@gcsu.edu \\ Peter W. Cardon, University of South Carolina, pcardon@sc.edu \\ Daniel T. Norris, University of South Carolina, dnorris@sc.edu \\ Natalya Goreva, Indiana University of Pennsylvania, natalya.goreva@iup.edu \\ Ryan D'Souza, University of South Carolina, dsouza@engr.sc.edu
}

\begin{abstract}
This study examined cross-national differences in the usage of social networking websites (SNWs) between university students in India and the United States. A total of 245 Indian university students and 241 American university students completed a survey about privacy attitudes and behaviors as well as communication patterns on SNWs. Many of the traditional propositions about cross-cultural values and related notions about trust and communication patterns did not explain differences in behavior between Indian and American students. In particular, Indian students, who are considered being from a collectivist society, and American students, who are considered being from an individualist society, exhibited many common communication patterns. When they did exhibit different communication patterns, Indian students reported communication behaviors considered significantly more individualist than the American students. This research suggests that additional cross-cultural research is needed about the usage of SNWs and other forms of computer-mediated communication.
\end{abstract}

Keywords: Social Networking Websites, Privacy, Cross-Cultural Communication, Computer-Mediated Communication

\section{INTRODUCTION}

Social networking websites (SNWs) have grown in popularity among all segments of society, but particularly among younger groups such as university students. Facebook is an example of the enormous amount of social interaction that occurs on these websites. Approximately $85 \%$ of all American university students at 4-year institutions use Facebook. There are 67 million active users worldwide, half of whom log in at least once each day for an average of twenty minutes. Approximately 250,000 people apply for profiles each day. Nearly 14 million photos are uploaded each day [12]. Of course, Facebook is just one of dozens and dozens of SNWs that each has millions of active users.

Popular business and news magazines such as BusinessWeek and Time run near-weekly articles about the impact of SNWs on business and society. SNWs are often pointed out as important forms of communication within the workplace and intriguing avenues for marketing, even changing the way business is done $[2,6,8]$. Other articles indicate that such optimism for usefulness in the workplace is exaggerated and that there are downfalls to social networking websites in the workplace $[1,15]$. They can consume bandwidth and storage consumption, create legal liabilities, expose a system to malware, decrease employee productivity, provide unwanted personal information about employees, and even risk publicizing secret corporate information [23].

For university students, SNWs have an equalizing effect in that people often feel the freedom to express themselves in ways not possible through other outlets. SNWs have even been identified as increasing self-esteem among younger people $[5,11$, $18,21]$. Yet, newspaper and magazine articles also point out the problems of content on SNWs being viewed by bosses and principals, resulting in some cases in being kicked out of school or losing jobs [19].

Since the enormous amount of social interaction facilitated by SNWs throughout the world is a fairly new phenomenon, research about cross-national differences in attitudes and usage of SNWs is particularly warranted. India and the United States are countries which engage in a great deal of online communication due to the rise in customer service, computer programming, and other service positions outsourced to India from the United States [22]. An understanding of cross-national differences among university students' attitudes toward and usage of SNWs can help provide insight into how crossnational virtual work will be conducted in the future. A great deal of research has been conducted about 
cross-cultural values and communication practices, yet scant research addresses how these findings apply to the online environment, particularly for SNWs.

\section{LITERATURE REVIEW}

SNWs are a relatively new form of online communication. The first SNW was SixDegrees.com, which was launched in 1997 . The current popularity of SNWs, however, is an even more recent phenomenon and it wasn't until 2003 when they were considered mainstream. The top two SNWs, MySpace and Facebook, began in 2003 and 2005, respectively [4]. In June 2007 these two websites combined for nearly 170 million unique visitors [7]. While the popularity of SNWs has become a global phenomenon, various websites have become market leaders in various countries and regions around the world: Orkut in Brazil and India, Mixi in Japan, LunarStorm in Sweden, Hi5 in smaller Latin American countries, Bebo in the United Kingdom, or Cyworld in Korea, to name a few. Each website contains features that appeal to the various national cultures [4].

Literature about SNWs is fairly limited and has mostly focused on impression management and security $[3,4,10,17,24]$. One consistent finding has been that SNWs are used primarily to sustain existing offline relationships - few users use SNWs to meet people [4]. However, no cross-cultural studies of SNWs are known to have been conducted. In a 2008 analysis of the literature on SNWs, Boyd and Ellison concluded that "scholars still have a limited understanding of who is and who is not using these sites, why, and for what purposes, especially outside of the U.S." (p. 15) [4].

In cross-cultural values and practices research, most researchers rely on the cultural dimensions developed by Geert Hofstede. Based on 116,000 survey responses from approximately 60 countries, he identified four cultural dimensions-individualism, uncertainty avoidance, power distance, and masculinity-which account for fundamental differences in work-related values among global societies [16]. William Gudykunst is among the foremost intercultural communication scholars who has identified how Hofstede's cultural dimensions influence trust and communication. $\mathrm{He}$ also developed the anxiety/uncertainty management (AUM) theory to describe how individuals and groups manage the inevitable anxiety and uncertainty involved in meeting and interacting with those who are not acquaintances (strangers) $[6,13,14]$.
Gudykunst identified individualism-collectivism as the most influential cultural dimension on trust and communication. Individualism involves the degree to which individuals should take care of themselves and become integrated into groups. Collectivist cultures tend to be more ambiguous, less direct, less open, less inclined to talk, and avoid confrontations; whereas individualist cultures tend to be more direct, more open, more inclined to talk, and more likely to directly address confrontations. Collectivists tend to interact with fewer friends but for longer periods of time. Individualists tend to interact with more people but for shorter periods of time. The Indian culture is considered medium to high in collectivism whereas the American culture is considered high in individualism $[14,16]$.

\section{RESEARCH METHODOLOGY}

This research was designed to make a cross-national comparison of Indian and American university students' attitudes toward and usage of SNWs. In particular, the following research questions were asked: (R1) What differences are there between Indian and American students in terms of privacy on SNWs? (R2) What differences are there between Indian and American students in terms of communication patterns on SNWs? (R3) To what degree do differences in collectivism and individualism in these two cultures explain the differences between Indian and American university students in terms of online privacy, trust, and communication patterns?

An online survey was created based on a survey conducted by the Pew Internet \& American Life Project among American teenagers [20]. Survey items were used that addressed attitudes towards privacy and behaviors to ensure online privacy. Also, survey items were selected that dealt with communication patterns. Survey items were slightly reworded for relevance to university students and several additional survey items were added. This survey provided a good basis for understanding basic cross-national differences in attitudes towards online privacy and communication. Since the survey responses were categorical in nature, results were analyzed with chi-square $(\chi 2)$ tests.

Altogether, 366 university students in India and 272 college students in the United States took the survey. Among the Indian participants, 245 students (66.9\%) indicated they had at least one profile on a social networking website and proceeded to complete the entire survey. Among American students, 241 students $(89.0 \%)$ did so. The university students in 
India were contacted through friend lists on SNWs by an Indian colleague of the researchers. His friend list contained approximately 200 friends and he encouraged his close friends to pass the survey link on to other university students. We are unable to identify the response rate since we cannot track how many potential Indian participants saw an invitation to take the survey. However, we believe the response rate was high since nearly all responses came in within one week, and we believe the invitation would have stopped being passed on fairly quickly. The American university students who took the survey were offered extra credit by instructors at four universities - two in the South, one in the East, and one in the West. Nearly all students who were offered the extra credit took the surveys.

\section{RESULTS}

When students were asked how public their profile was (as illustrated in Table 1), the majority of Indian university students $(69.5 \%)$ make their profile visible for anyone to see compared to roughly a quarter of American students (28.6\%) who make their profiles public. American students $(66.0 \%)$ are far more likely to make their profiles only visible to friends compared to less than one fourth of Indian students $(22.8 \%)$ who do so. Small percentages of American students $(5.3 \%)$ and Indian students $(7.7 \%)$ do not know to whom their profiles are visible.

Table 1. Public Nature of Online Profile

\begin{tabular}{|c|c|c|}
\hline $\begin{array}{l}\text { How public is your } \\
\text { profile? }\end{array}$ & $\begin{array}{l}\text { India } \\
(n=259)\end{array}$ & $\begin{array}{l}\text { USA } \\
(n=241)\end{array}$ \\
\hline visible to anyone & $180(69.5 \%)$ & $69(28.6 \%)$ \\
\hline $\begin{array}{l}\text { visible only to } \\
\text { friends }\end{array}$ & $59(22.8 \%)$ & $159(66.0 \%)$ \\
\hline $\begin{array}{cc}\text { don't know to } \\
\text { whom } & \text { it's } \\
\text { visible } & \end{array}$ & $20(7.7 \%)$ & $13(5.3 \%)$ \\
\hline
\end{tabular}

Table 2. Attitudes toward Sharing Information Online

\begin{tabular}{|c|c|c|c|c|c|c|}
\hline $\begin{array}{l}\text { Please tell me if you think it is okay to share the } \\
\text { following information with someone you just met } \\
\text { on the Internet: }\end{array}$ & India & USA & $\chi^{2}$ & $N$ & $d f$ & $p$ \\
\hline state where you live & $176(72.1 \%)$ & $162(67.2 \%)$ & 1.38 & 485 & 1 & 0.239 \\
\hline school name & $183(75.3 \%)$ & $190(78.8 \%)$ & 0.85 & 484 & 1 & 0.356 \\
\hline IM screen name & $132(55.5 \%)$ & $145(60.7 \%)$ & 1.33 & 484 & 1 & 0.249 \\
\hline city or town where you live & $190(78.2 \%)$ & $128(53.1 \%)$ & 33.8 & 477 & 1 & $0.000 * *$ \\
\hline last name & $164(68.0 \%)$ & $114(47.5 \%)$ & 20.8 & 484 & 1 & $0.000 * *$ \\
\hline email address & $158(65.3 \%)$ & $128(53.3 \%)$ & 7.14 & 481 & 1 & $0.008 * *$ \\
\hline your blog or a link to your blog & $109(45.6 \%)$ & $110(45.6 \%)$ & 0.00 & 482 & 1 & 0.994 \\
\hline cell phone number & $33(13.8 \%)$ & $30(12.4 \%)$ & 0.18 & 480 & 1 & 0.672 \\
\hline
\end{tabular}

Note. ${ }^{*} p<.05 ; * * p<.01$

Table 3. Types of Information Provided on SNWs

\begin{tabular}{|c|c|c|c|c|c|c|}
\hline $\begin{array}{l}\text { We would like to know if the following kinds of } \\
\text { information are posted to your profile, or not. } \\
\text { You can just tell me yes or no. On your profile, } \\
\text { do you provide...? }\end{array}$ & India & USA & $\chi^{2}$ & $N$ & $d f$ & $p$ \\
\hline First name & $232(93.2 \%)$ & $231(95.9 \%)$ & 1.69 & 490 & 1 & 0.194 \\
\hline $\begin{array}{l}\text { Last name } \\
\text { Photos of friends }\end{array}$ & $\begin{array}{l}200(81.3 \%) \\
129(52.4 \%)\end{array}$ & $\begin{array}{l}214(89.2 \%) \\
219(91.3 \%)\end{array}$ & $\begin{array}{l}5.96 \\
90\end{array}$ & $\begin{array}{l}486 \\
486\end{array}$ & $\begin{array}{l}1 \\
1\end{array}$ & $\begin{array}{l}0.015 * \\
0.000 * *\end{array}$ \\
\hline Photos of yourselves & $168(68.6 \%)$ & $230(95.4 \%)$ & 59.1 & 486 & 1 & $0.000 * *$ \\
\hline City or town & $228(91.9 \%)$ & $214(88.8 \%)$ & 1.39 & 489 & 1 & 0.239 \\
\hline Link to their blog & $75(31.0 \%)$ & $43(18.0 \%)$ & 11 & 481 & 1 & $0.001 * *$ \\
\hline School's name & $193(79.1 \%)$ & $233(96.7 \%)$ & 35.1 & 485 & 1 & $0.000 * *$ \\
\hline $\begin{array}{l}\text { IM screen name } \\
\text { email address }\end{array}$ & $\begin{array}{l}127(52.9 \%) \\
215(87.0 \%)\end{array}$ & $\begin{array}{l}121(50.8 \%) \\
172(71.4 \%)\end{array}$ & $\begin{array}{l}0.21 \\
18.3\end{array}$ & $\begin{array}{l}478 \\
488\end{array}$ & $\begin{array}{l}1 \\
1\end{array}$ & $\begin{array}{l}0.650 \\
0.000 * *\end{array}$ \\
\hline stream audio or MP3 files & $56(23.4 \%)$ & $60(25.21 \%)$ & 0.21 & 477 & 1 & 0.651 \\
\hline
\end{tabular}

Note. ${ }^{*} p<.05 ; * * p<.01$ 
When asked about attitudes toward sharing information on SNWs (as illustrated in Table 2), Indian and American university students showed many similarities and differences. There was no significant difference in terms of thinking it was okay to share the state where you live, school name (India: 72.1\%; USA: 67.2\%), IM screen name (India: 55.5\%; USA: $60.7 \%$ ), or a link to a personal blog (India: 45.6\%; USA: $45.6 \%$ ). There was also not a difference in attitudes toward sharing a cell phone number online with someone you just met - just $13.8 \%$ of Indian and $12.4 \%$ of American university students thought this was okay. Indian students were significantly more likely to think it was okay to share the city or town where one lives (India: $78.2 \%$; USA: $53.1 \%$ ), one's last name (India: $68.0 \%$; USA: $47.5 \%$ ), and one's email address (India: $65.3 \%$; USA: $53.3 \%$ ); however, it should be noted that approximately half of American university students thought it was okay to share each of these items.

When asked about types of information that students provide on SNWs (as illustrated in Table 3), Indian students and American students nearly always provide first names (India: 93.2\%; USA: 95.9\%), last names (India: $81.3 \%$; USA: $89.2 \%$ ), and city or town where they live (India: 91.9\%; USA: 88.8\%). American students were significantly more likely to upload photos of friends (India: 52.4\%; USA: 91.3\%), upload photos of themselves (India: 68.6\%; USA: 95.4\%), and provide a school name (India: $79.1 \%$; USA: 96.7\%). Indian students were significantly more likely to provide email addresses (India: $87.0 \%$; USA: $71.4 \%$ ) and links to their blogs (India: $31.0 \%$; USA: 18.0\%).

When asked how they would respond to a complete stranger who initiates contact (as illustrated in Table 4), American students were far more likely to simply ignore the communication (India: 46.9\%; USA: $74.3 \%$ ) whereas Indian students were far more likely to respond and find out more about the person (India: 44.0\%; USA: $24.1 \%$ ). Indian students were also far more likely to directly tell the stranger to leave them alone (India: 9.1\%; USA: 1.7\%)

When asked from where students most frequently accessed their SNWs (as illustrated in Table 5), American students were more likely to do so from home (India: $66.8 \%$; USA: $75.9 \%$ ) or school (India: $6.9 \%$; USA: $17.8 \%$ ). Indian students were more likely to access SNWs from someplace else (India: $22.7 \%$; USA: $2.9 \%$ ), which probably indicates Internet cafés.
In terms of specific ways in which students use SNWs to communicate with friends (as illustrated in Table 6), Indians and Americans were quite similar in the practices of posting messages to a friend's page, space, or wall (India: 89.6\%; USA: 94.6\%); sending a bulletin or group message to all friends (India: $51.6 \%$; USA: $57.9 \%$ ); and posting comment's to a friend's blog (India: 45.3\%; USA: 53.8\%). American university students were far more likely, however, to send private messages to a friend within the social networking system (India: 65.9\%; USA: 92.9\%).

Table 4. Online Contact Initiated by Strangers

\begin{tabular}{|c|c|c|}
\hline $\begin{array}{l}\text { Thinking about the } \\
\text { last time you were } \\
\text { contacted online by } \\
\text { someone who was a } \\
\text { complete stranger to } \\
\text { you, how did you } \\
\text { respond? }\end{array}$ & India $(n=)$ & USA (n = ) \\
\hline Just ignored it & $114(46.9 \%)$ & $179(74.3 \%)$ \\
\hline $\begin{array}{l}\text { Responded so I could } \\
\text { find out more } \\
\text { about the person }\end{array}$ & $107(44.0 \%)$ & $58(24.1 \%)$ \\
\hline $\begin{array}{l}\text { Responded and told } \\
\text { them to leave me } \\
\text { alone }\end{array}$ & $22(9.1 \%)$ & $4(1.7 \%)$ \\
\hline
\end{tabular}

Table 5. Location From Which Access SNWs

\begin{tabular}{lll}
\hline $\begin{array}{l}\text { From where do } \\
\text { access your social } \\
\text { networking website }\end{array}$ & & \\
most often? & & \\
\hline home & $165(66.8 \%)$ & $183(75.9 \%)$ \\
school & $17(6.9 \%)$ & $43(17.8 \%)$ \\
someplace else & $56(22.7 \%)$ & $7(2.9 \%)$ \\
don't know & $9(3.6 \%)$ & $8(3.3 \%)$ \\
\hline $\begin{array}{l}\text { Note. }\left(\chi^{2}(2, N=484)=50.30, p=.000\right) \\
* p<.05 ; * * p<.01\end{array}$ &
\end{tabular}

When asked about how many friends they make at least weekly contact with (as illustrated in Table 7), Indian and American students were fairly comparable and there are not significant differences. Indian university students tend to have slightly more online friends with whom they communicate frequently than offline friends. Whereas higher percentages report having 1 to 4 or (offline: $19.7 \%$; online: $15.4 \%$ ) 5 to 9 offline friends (offline: $32 . \% \%$; online: $26.9 \%$ ), higher percentages report having 10 to 14 (offline: $16.7 \%$; online: $17.9 \%$ ), 15 to 19 (offline: $10.7 \%$; online: $12.8 \%$ ), 20 to 29 (offline: $6.8 \%$; online: 
Table 6. Communication Methods on SNWs

\begin{tabular}{|c|c|c|c|c|c|c|}
\hline $\begin{array}{l}\text { We'd like to know the specific ways you } \\
\text { communicate with your friends using social } \\
\text { networking sites. Do you ever...? }\end{array}$ & India & USA & $\chi^{2}$ & $N$ & $d f$ & $p$ \\
\hline post messages to a friend's page, space or wall & $223(89.6 \%)$ & $228(94.6 \%)$ & 4.26 & 490 & 1 & $0.039^{*}$ \\
\hline $\begin{array}{l}\text { send private messages to a friend within the social } \\
\text { networking system }\end{array}$ & $162(65.9 \%)$ & $222(92.9 \%)$ & 53.73 & 485 & 1 & $.000 * *$ \\
\hline $\begin{array}{l}\text { send a bulletin or group message to all of your } \\
\text { friends }\end{array}$ & $126(51.6 \%)$ & $139(57.9 \%)$ & 1.92 & 484 & 1 & 0.165 \\
\hline post comments to a friend's blog & $110(45.3 \%)$ & $129(53.8 \%)$ & 3.46 & 483 & 1 & 0.062 \\
\hline
\end{tabular}

Note. ${ }^{*} p<.05 ; * * p<.01$

Table 7. Online Versus Offline Friends

\begin{tabular}{|c|c|c|c|c|c|c|c|c|}
\hline \multicolumn{2}{|c|}{$\begin{array}{l}\text { How many friends do you } \\
\text { keep regular contact with } \\
\text { each week? }\end{array}$} & $\mathbf{0}$ & 1 to 4 & 5 to 9 & 10 to 14 & 15 to 19 & 20 to 29 & 30 or more \\
\hline India & In offline-life & $8(3.4 \%)$ & $46(19.7 \%)$ & $76(32.5 \%)$ & $39(16.7 \%)$ & $25(10.7 \%)$ & $16(6.8 \%)$ & $24(10.3 \%)$ \\
\hline & In online life & $8(3.4 \%)$ & $36(15.4 \%)$ & $63(26.9 \%)$ & $42(17.9 \%)$ & $30(12.8 \%)$ & $23(9.8 \%)$ & $32(13.7 \%)$ \\
\hline & $\begin{array}{l}\text { In online life } \\
\text { (friends who have } \\
\text { never met before) }\end{array}$ & $63(26.5 \%)$ & $103(43.3 \%)$ & $37(15.5 \%)$ & $12(5.0 \%)$ & $9(3.8 \%)$ & $5(2.1 \%)$ & $9(3.8 \%)$ \\
\hline \multirow[t]{3}{*}{ USA } & In offline-life & $2(0.9 \%)$ & $40(17.7 \%)$ & $58(25.7 \%)$ & $48(21.2 \%)$ & $32(14.2 \%)$ & $29(12.8 \%)$ & $17(7.5 \%)$ \\
\hline & In online life & $11(4.8 \%)$ & $45(19.8 \%)$ & 44 (19.4\%) & $53(23.3 \%)$ & $27(11.9 \%)$ & $22(9.7 \%)$ & $25(11.0 \%)$ \\
\hline & $\begin{array}{l}\text { In online life } \\
\text { (friends who have } \\
\text { never met before) }\end{array}$ & $183(77.5 \%)$ & $36(15.3 \%)$ & $5(2.1 \%)$ & $6(2.5 \%)$ & $2(0.8 \%)$ & $2(0.8 \%)$ & $2(0.8 \%)$ \\
\hline
\end{tabular}

Note. For offline-life: $\left(\chi^{2}(7, N=488)=14.01, p=.051\right)$; For online life: $\left(\chi^{2}(7, N=487)=7.87, p=.344\right)$; For online life (friends who have never met before): $\left(\chi^{2}(7, N=483)=128.37, p=.000 * *\right)$.

$* p<.05 ; * * p<.01$

$9.8 \%$ ), or 30 or more online friends (offline: $10.3 \%$; online: $13.7 \%$ ).

Collectively, over half of Indian students (54.2\%) have more than 10 online friends with whom they interact weekly, compared to $44.5 \%$ who have more than 10 offline friends with whom they interact weekly. Among American university students, roughly the same percentages report having the same number of offline and online friends with whom they interact weekly.

When asked about the number of online friends who university students have never met in person, Indian students reported far more contact. While nearly all American students (77.5\%) reported having no online friends who they had never met before, about the same percentage of Indian students $(73.5 \%)$ reported having online friends who they had never met before.

In terms of content published or communicated on SNWs (as illustrated in Table 8), high percentages of both Indian and American students communicated about personal hobbies (India: $80.3 \%$; USA: $86.6 \%$ ), music (India: 74.3\%; USA: 86.6\%), movies/TV (India: 74.3\%; USA: 86.6\%), friendships (India:
$76.6 \%$; USA: $79.9 \%$ ), other entertainment (India: 63.4\%; USA: 54.9\%), sports (India: 63.1\%; USA: 66.8\%), jobs/work (India: 53.5\%; USA: 58.4\%), and religion/spirituality (India: 45.1\%; USA: 50.0\%). Indian students were far more likely to publish or communicate about games (India: 57.3\%; USA: 39.7\%), health issues (India: 25.4\%; USA: 8.9\%), shopping (India: $34.4 \%$; USA: $18.9 \%$ ), and fashion (India: 37.4\%; USA: 17.3\%). American students were far more likely to publish or communicate about social events/parties (India: 47.8\%; USA: 68.5\%), romance (India: 29.4\%; USA: 53.8\%), and school/homework (India: 30.2\%; USA: 49.2\%). As far as the total number of content items selected, Indian students on average selected $8.53(\mathrm{SD}=4.29)$ compared to American students who on average selected $9.03(\mathrm{SD}=3.49)$.

\section{CONCLUSIONS}

In our study we intended to identify cross-national differences in online privacy (R1) and communication patterns on SNWs (R2). In addition, we intended to identify the degree to which the American individualist culture and the Indian collectivist culture explained these variations (R3). 
We describe our conclusions in three sections. The

American students are far more likely to simply

Table 8. Content Published or Communicated on SNWs

\begin{tabular}{lllllll}
\hline $\begin{array}{l}\text { What content do you publish or } \\
\text { communicate about on your } \\
\text { social networking website? }\end{array}$ & India & USA & $\chi 2$ & $\boldsymbol{N}$ & $\boldsymbol{d} \boldsymbol{f}$ & $\boldsymbol{p}$ \\
\hline Personal Hobbies & & & & & & \\
Music & $192(80.3 \%)$ & $207(86.6 \%)$ & 3.41 & 478 & 1 & .065 \\
Movies/TV & $179(74.3 \%)$ & $207(86.6 \%)$ & 11.58 & 480 & 1 & $.001^{* *}$ \\
Games & $176(74.3 \%)$ & $206(86.6 \%)$ & 11.40 & 475 & 1 & $.001^{* *}$ \\
Other entertainment (besides & $133(57.3 \%)$ & $95(39.7 \%)$ & 14.57 & 471 & 1 & $.000^{* *}$ \\
$\quad 147(63.4 \%)$ & $130(54.9 \%)$ & 3.51 & 469 & 1 & .061 \\
$\quad$ & & & & & \\
gamusic, movies/TV, and & & & & & & $.000^{* *}$ \\
Rocial events/parties & $109(47.8 \%)$ & $163(68.5 \%)$ & 20.50 & 466 & 1 & $.000^{* *}$ \\
Friendships & $67(29.4 \%)$ & $128(53.8 \%)$ & 28.48 & 466 & 1 & .381 \\
School/homework & $180(76.6 \%)$ & $191(79.9 \%)$ & .77 & 474 & 1 & $.000^{* *}$ \\
Jobs/Work & $68(30.2 \%)$ & $117(49.2 \%)$ & 17.29 & 463 & 1 & .283 \\
Politics & $123(53.5 \%)$ & $139(58.4 \%)$ & 1.15 & 468 & 1 & .084 \\
Religion/Spirituality & $68(29.7 \%)$ & $89(37.2 \%)$ & 2.99 & 468 & 1 & .284 \\
Sports & $105(45.1 \%)$ & $119(50.0 \%)$ & 1.15 & 471 & 1 & .398 \\
Health issues & $147(63.1 \%)$ & $159(66.8 \%)$ & .72 & 471 & 1 & $.000^{* *}$ \\
Shopping & $58(25.4 \%)$ & $21(8.9 \%)$ & 22.27 & 463 & 1 & $.000^{* *}$ \\
Fashion & $78(34.4 \%)$ & $45(18.9 \%)$ & 14.26 & 465 & 1 & $.000^{* *}$ \\
Travel/Vacations & $85(37.4 \%)$ & $41(17.3 \%)$ & 23.79 & 464 & 1 & .121 \\
\hline Note. $p<.05 ; *<.01$ & $82(36.8 \%)$ & $71(30.0 \%)$ & 2.40 & 460 & 1 & \\
\hline
\end{tabular}

Note. ${ }^{*} p<.05 ; * * p<.01$

first section addresses online privacy (R1). The second question addresses online communication patterns (R2). We include our analysis about the impact of individualism and collectivism within each of the first two sections (R3). We conclude with a section about future research about cross-national differences on SNWs.

\section{Online Privacy on SNWs}

Generally, American university students are far more cautious than Indian students about online privacy on their SNWs. They are much more likely to only allow friends to view their profiles and less likely to think it is okay to share various types of information online (such as last name or email address). However, American students also tend to be more likely to provide information online that identifies them, such as last name, photos, and school name. Indian students, by contrast, tend to be less cautious about online privacy on SNWs and are more likely to interact with strangers who initiate contact with them. Furthermore, Indian students are far more likely to directly ask strangers to leave them alone and ignore unwanted communications. These findings are in contrast with traditional understanding of collectivist and individualist communication patterns. Individualists tend to be more trusting, open, and direct in exchanges with strangers, whereas collectivists tend to be less trusting and evasive in unwanted exchanges.

\section{Online Communication Patterns on SNWs}

In terms of online communication patterns, Indian and American students who use SNWs are quite similar in terms of posting messages to friend's pages, sending bulletins or group messages to all of their friends, and posting comments to friends' blogs. However, Indian students far less frequently send private messages to a friend within the social networking system. This may indicate the collectivist mentality of Indians in that communications are more often to be shared among social networks.

Indian and American students did not show significant differences in the number of online versus offline friends with whom they make at least weekly 
contact. Furthermore, they tend to have roughly equal numbers of online and offline friends, although Indian students who have many friends (10 or more) tend to have slightly more online than offline friends. These findings are interesting for several reasons. First, this indicates the pervasive nature of SNWs in the lives of Indian and American students in that their circle of online friends is at least as large as their circle of offline friends (of course, many of these friends fall into both categories). Second, this is not in line with traditional assumptions about individualists and collectivists in that in offline environments individualists interact with more friends but for shorter periods of time whereas collectivists interact with fewer friends for longer periods of time.

It is also particularly striking that Indian students are far more likely to maintain a circle of online friends with whom they have never met face-to-face. Generally, individualists are assumed to be more trusting, active, and mobile in developing friendships. Also, this tends to illustrate that existing literature, which identifies making friends as a rather insignificant aspect of SNWs, may be culturally based. While this study seems to indicate that small percentages of Americans use SNWs to make friends and thus confirm other studies of Americans in this regard, it also indicates that Indian students are prolific in making and sustaining friendships online.

Finally, the research showed that Indian and American students communicate and publish on their SNWs about a wide array of topics. For both groups, publishing about entertainment and personal hobbies are extremely popular. American students are more likely to use SNWs to arrange offline activities, such as social events, parties, and coordinating schoolwork. Again, this indicates the stronger American tendency to focus on SNWs as sustaining existing relationships.

\section{Future Research about Cross-Cultural Differences on SNWs}

Clearly, cross-cultural research about the use of SNWs is required for several reasons. First, this research illustrates that online privacy and communication behaviors do not match traditional understanding of cross-cultural differences. In this case, Indian and American university students did not exhibit many of the contrasting behaviors associated with collectivists and individualists. There may be several reasons for this. The medium itself (SNWs) may explain some of these differences and, thus, is cause for additional research. Also, globalization may have caused some convergence of cultures, causing less collectivist attitudes and behaviors among Indian students and more collectivist attitudes and behaviors among American students. However, globalization itself is spread through online forums such as the SNWs. Thus, if this is the case, additional research in how SNWs contribute to this change is required. Second, the appeal of SNWs among university students indicates that such technologies will be increasingly important tools for the workplace. Indeed, as individuals who grew up using SNWs enter the workforce, their very expectations for how work should be done may profoundly affect how work is managed. Likewise, with increasing numbers of virtual teams composed of members of different cultures, the need to understand cultural variation on attitudes and usage on SNWs will become more relevant.

\section{REFERENCES}

1. Ante, S. E., \& Holahan, C. (2008, February 18). Generation MySpace is getting fed up. Business Week, 4071, 54-55.

2. Baker, S., \& Green, H. (2008, February 20). Social media will change your business. Business Week.

3. Barnes, S. (2006). A privacy paradox: Social networking in the United States. First Monday, 11(9), article 5. Retrieved March 10, 2008, from http://www.firstmonday.org/issues/issue11_9/bar nes/

4. Boyd, D. M., \& Ellison, N. B. (2007). Social network sites: Definition, history, and scholarship. Journal of Computer-Mediated Communication, 13(1), article 11.

5. Bush, J. (2008, February 25). The blogging czar of Russia. Business Week, 4072.

6. Cobo, L. (2008, March 1). Social networking in Spanish. Billboard, 120(9), 20-21.

7. comScore. (2007, July 31). Social networking goes global. Retrieved March 10, 2008, at http://www.comscore.com/press/release.asp?pres $\mathrm{s}=1555$

8. Cooke, M., \& Buckley, N. (2007). Web 2.0, social networks and the future of market research. International Journal of Market Research, 50(2), 267-292.

9. Duronto, P. M., Nishida, T., \& Nakayama, S.-I. (2005). Uncertainty, anxiety, and avoidance in 
communication with strangers. International Journal of Intercultural Relations, 29,549-460.

10. Dwyer, C., Hiltz, S. R., \& Passerini, K. (2007). Trust and privacy concern within social networking sites: A comparison of Facebook and MySpace. Proceedings of the AMCIS 2007, Keystone, CO. Retrieved March 10, 2008, from http://csis.pace.edu/ dwyer/research/DwyerAM CIS2007.pdf

11. Ellison, N. B., Steinfield, C., \& Lampe, C. (2007). The benefits of Facebook "friends:" Social capital and college students' use of online social network sites. Journal of ComputerMediated Communication, 12(4), article 1.

12. Facebook. (2008, March 11). Statistics. Retrieved March 11, 2008, from http://www.facebook.com/press/info.php?statisti cs

13. Gudykunst, W. B. (1998). Applying anxiety/uncertainty management (AUM) theory to intercultural adjustment training. International Journal of Intercultural Relations, 22(2), 227250.

14. Gudykunst, W. B., \& Kim, Y. Y. (1997). Communicating with strangers: An approach to intercultural communication ( $3^{\text {rd }}$ ed.). New York: McGraw-Hill.

15. Hamilton, A. (2007, December 3). Is Facebook overrated? Time, 170(23), 48-51.

16. Hofstede, G. (2001). Culture's consequences: Comparing values, behaviors, institutions, and organizations across nations ( $2^{\text {nd }}$ ed.). Thousand Oaks, CA: Sage.
17. Jagatic, T., Johnson, N., Jakobsson, M., \& Menczer, F. (2007). Social phishing. Communications of the ACM, 5(10), 94-100.

18. Kim, K.-H., \& Yun, H. (2007). Cying for me, cying for us: Relational dialectics in a Korean social network site. Journal of ComputerMediated Communication, 15(1), article 11.

19. Kornblum, J., \& Marklein, M. B. (2006, March 8). What you say online could haunt you. USA Today. Retrieved March 10, 2008, from http://www.usatoday.com/tech/news/internetpriv acy/2006-03-08-facebook-myspace_x.htm

20. Lenhart, A., \& Madden, M. (2007, April 18). Teens, privacy \& online social networks: How teens manage their online identities and personal information in the age of MySpace. Washington, D.C.: Pew Internet \& American Life Project.

21. Miura, A., \& Yamashita, K. (2007). Psychological and social influences on blog writing: An online survey of blog authors in Japan. Journal of Computer-Mediated Communication, 12(4), article 15.

22. Pal, M., \& Buzzanell, P. (2008). The Indian call center experience. Journal of Business Communication, 45(1), 31-60.

23. Perkins, B. (2008, February 11). The pitfalls of social networking. ComputerWorld, 44.

24. Stutzman, F. (2006). An evaluation of identitysharing behavior in social network communities. Journal of the International Digital Media and Arts Association, 3(1), 10-18. 